\title{
Metode Pembelajaran Bahasa Asing (Jerman) dan Sekelumit Perkembangannya
}

\author{
Syamsu Rijal' dan Syarifah Fatimah ${ }^{2}$ \\ Fakultas Bahasa dan Sastra, Universitas Negeri Makassar \\ Email: syamsu.rijal@unm.ac.id
}

E-ISSN : 2579-4574

P-ISSN : 2549-7359

\begin{abstract}
The method as one of the important components in the learning process needs to be better understood, because the success or failure of a learning goal depends on the type and application of the chosen method. This paper presents five types of methods that are commonly understood in learning German as a foreign language (Deutsch als Fremdsprache), namely: Grammatik-Übersetzungsmethode, direkte Methode, Audio-linguale Methode, Kommunikative Methode, interkulturelle Ansatz. These five types of methods are presented chronically to describe the process of developing the foreign (German) language learning method.
\end{abstract}

Keywords: Learning Method, German, Language Learning

https://ojs.unm.ac.id/eralingua

\section{PENDAHULUAN}

Metode pembelajaran merupakan salah satu komponen penting dalam pencapaian tujuan pengajaran. Penggunaan metode pengajaran tertentu akan sangat bergantung pada tujuan pengajaran itu sendiri. Kesalahan dalam memilih metode akan berakibat pada sulitnya mencapai tujuan pengajaran. Dengan kata lain, tujuan pengajaran akan selalu searah dengan metode yang digunakan. Di samping tujuan pengajaran, penggunaan atau pemilihan suatu metode biasanya ditentukan oleh beberapa faktor diantaranya: Konsep pembelajaran negara bahasa tujuan; Tradisi proses belajar-mengajar di suatu negara; Pengaruh perkembangan ilmu khususnya ilmu bahasa; Tujuan pembelajaran secara spesifik, misalnya bahasa Jerman untuk pariwisata, bahasa Jerman untuk sekretaris dan lain-lain.; Kondisi pembelajar, misalnya bakat bahasa, tempo pembelajaran atau mungkin kelompok pembelajar memiliki hal-hal spesifik yang mesti diperhatikan.

Methodos dalam bahasa Yunani atau methodus dalam bahasa Latin artinya alat atau jalan yang gunakan untuk mencapai tujuan tertentu. Secara sempit pengertian metode dalam pembelajaran bahasa asing yakni tindakan atau perlakuan atau pola kegiatan yangberulang- ulang yang sesuai dalam proses belajar-mengajar. Namun secara luas metode dapat diartikan sebagai konsep yang digunakan untuk pemilihan, penjenjangan dan pengelompokan bahan ajar. Lebih rinci, Apelt (1972: 8) mengemukakan bahwa metode adalah suatu strategi khusus yang digunakan untuk mencapai tujuan yang telah direncanakan secara sistematik dan berorientasi pada hasil. Mengingat pentingnya metode dalam pemerolehan bahasa asing, maka dalam 
dalam tulisan ini akan diuraikan beberapa metode yang selama ini digunakan dalam pengajaran bahasa asing.

\section{HASIL DAN PEMBAHASAN}

\section{Grammatik-Übersetzungsmethode}

Grammatik-Übersetzungsmethodeyang secara harfiah dapat diartikan sebagai metode tatabahasa dan terjemahanadalah salah satu metode pengajaran bahasa asing (Jerman) dengan tujuan utama adalah penguasaantatabahasa dan kosakata. Kedua kemampuan ini kemudian digunakan untuk menerjemahkan teks-teks bahasa asing yang dipelajari.Grammatik-Übersetzungsmethode termasuk metode klasik dalam pengajaran bahasa asing yang telah digunakan dan dikembangkan sejak abad pertengahan. Pada awalnya pengajaran bahasa asing diarahkan semata-mata untuk penguasaan kemampuan menulis bahasa tujuan dan proses belajar-mengajar hanya terbatas pada lingkungan gereja dengan tujuan utama adalah penerjemahan kitab injil ke berbagai bahasa. Buku pelajaran bahasa yang sangat terkenal yang ditulis pada abad ke 4 oleh Aelius Donatus dan masih digunakan sampai abad ke 19 oleh Ars Grammatica, terutama bagian de partibus orationis ars minor. Sebagai sebuah metode, Grammatik-Übersetzungsmethode dikenal secara resmi di Eropa sejak akhir abad ke 18 dan digunakan terutama dalam pengajaran bahasa Perancis dan bahasa Inggris. Posisi kuat metode ini terutamasampai menjelang akhir perang dunia kedua. Dewasa ini Grammatik-Übersetzungsmethode masih tetap digunakan baik secara utuh maupun sebagai elemen pelengkap dalam proses pembelajaran bahasa asing.

Tujuan pengajaran yang hendak dicapai dengan menggunakan GrammatikÜbersetzungsmethode yakni penguasaan tatabahasa dan kemampuan menerjemahkan dari pembelajar. Hal ini terungkap dari prinsip metode ini: "Wer die Grammatik beherrscht, beherrscht die fremde Sprache und wer korrekt übersetzen kann, zeigt damit, dass er die fremde Sprache wirklich beherrscht." Dari prinsip ini dapat dipahami bahwa siapa yang menguasai gramatika suatu bahasa asing, berarti dia menguasai bahasa tersebut dan siapa yangmampu menerjemahkan dengan benar menunjukkan bahwa dia betul-betul menguasai bahasa tersebut. Jadi dalam metode ini menguasai gramatika bahasa asing dan menghapal sepenuhnya kosakatanya adalah tujuan utama dari metode ini. Dengan demikian orientasi akhir dari metode ini adalah semata-mata kompetensi gramatika atau „grammatische Kompetenz als Ziel“.

Adapun tahap-tahap pembelajaran dengan menggunakan metodeGrammatik-Übersetzungsmethode ini yakni:

- Einführungsphase atau tahap pengantar: Pada tahap ini pengajar menjelaskan sepenuhnya gramatika bahasa asing (Jerman) yang sedang dipelajari.

- Übungsphase atau tahap latihan yakni pembelajar berlatih membuat kalimat sesuai dengan pola gramatik yang diajarkan.

- Anwendungsphase atau tahap penerapan. Pada tahap ini pembelajar akan menggunakan pola gramatika dan kosakata yang telah dipelajari. Pada tahap 
ini pembelajar melakukan kegiatan membaca, menulis kemudian menerjemahkan.

Lesen $\rightarrow$ Schreiben $\rightarrow$ Übersetzen

Perlu dicatat bahwa bahasa pengantar yang digunakan dalam proses pembelajaran yang menggunakan Grammatik-Übersetzungsmethode dalam bahasa ibu. Adapun bentuk-bentuk latihan yang digunakan dalam penerapan metode ini antara lain:

- Menerjemahkan kalimat ataupun teks yang lebih panjang dari bahasa ibu ke bahasa sasaran (Jerman) atau sebaliknya dalam kaitannya dengan gramatika yang sedang dipelajari.

- Menerjemahkan teks-teks sastra Jerman ke dalam bahasa ibu.

- Membaca teks-teks sastra Jerman.

- Menulis kesimpulan isi suatu teks atau melanjutkan cerita suatu teks.

- Mengisi bagian-bagian kosong suatu teks.

- Diktat atau mendikte.

Dalam penerapan metode ini guru menjadi titik pusat yang bersifat autoriter dan maha tahu (Alleswisser) dengan menggunakan model pembelajaran kelas frontal. Sementara pelajar memposisikan diri untuk bisa senantiasa memahami isi dan bentuk-bentuk teks yang diajarkan. Mereka tentu dituntut untuk bisa menerjemahkan teks-teks yang diajarkan baik ke dalam bahasa sasaran maupun ke dalam bahasa ibu mereka. Dari penjelasan di atas dapat disimpulkan bahwa Grammatik-Übersetzungsmethode adalah metode yang bersifat synthetisch-deduktiv artinya adalah pemerolehan bahasa asing melalui berbagai macam aturan atau pola gramatika untuk kemudian diterapkan. Metode ini juga tidak berorientasi pada penguasaan bahasa tujuan secara praktis dan sangat terfokus pada penguasaan gramatika, jadi hanya berkutat pada peningkatan kemampuan yang bersifat kognitif semata.

\section{Direkte Methode}

Kehadiran direkte Methode atau metode langsung merupakan jawaban atas kritikan terhadap Grammatik-Übersetzungsmethode. Wilhelm Vietor (1882) yang mempelopori munculnya direkte Methode mengungkapkan bahwa bahasa-bahasa yang masih hidup tidak bisa dipelajari dengan bantuan bahasa yang sudah punah atau mati. Hal ini salah satu kritikan terhadapGrammatik-Übersetzungsmethode yang menjadikan bahasa Latin sebagai acuan dalam mempelajari bahasa asing. Dari segi kosakata dikemukakan bahwa bahasa pada dasarnya tidaklah terdiri dari kata demi kata, tertapi terdiri dari kalimat-kalimat. Autoritas guru, penggunaan bahasa ibu dan model pembelajaran yang bersifat mekanis (penghafalan) adalah bagian lain dari kritikan-kritikan terhadap Grammatik-Übersetzungsmethode. Di samping itu keterampilan berbicara yang dialogis dan situatif tidak dimungkinkan dengan Grammatik-Übersetzungsmethode.

Direkte Methode yang mulai dikembangkan sejak awal abad ke 19 memberikan postulat yang menegaskan bahwa mempelajari bahasa asing sebaiknya dimulai dengan bacaan atau teks-teks sederhana; pelajaran gramatika diperuntukkan bagi pembelajar yang sudah berada pada tingkat lanjutan; belajar 
bahasa sebaiknya dengan bermain dan bergerak; perlunya mempelajari bahasa pergaulan sehari-hari (Umgangsprache) dalam percakapan. Tujuan yang ingin dicapai dalam penggunaan metode langsung ini adalah: Mengembangkan perasaan bahasa; mempelajari Umgangsprache dalam percakapan berarti mempelajari bahasa secara natural; mempelajari bahasa asing sebaiknya dipisahkan dari sistem bahasa ibu; pembelajaran dilakukan melalui permainan, gerakan-gerakan dan meniru apa yang diungkapkan oleh pengajar. Bentuk-bentuk latihan yang biasa digunakan dengan menggunakan metode langsung adalah:

- Latihan bertanya dan menjawab

- Latihan meniru (latihan pengucapan/Ausspracheübungen).

- Mengisi atau melengkapi teks-teks yang kosong.

- Bermain peran berdasarkan dialog-dialog tertentu.

- Melafalkan rima karya-karya sastra.

- Sekali-kali memberikan dikte dan latihan melanjutkan isi teks.

- Latihan gramatik diberikan hanya di akhir setiap materi pembelajaran.

Adapun media yang digunakan adalah gambar-gambar, berbagai macam benda, media audio (kaset atau CD). Peranan pengajar dalam penerapan direkte Methode lebih aktif dari penerapan Grammatik-Übersetzungsmethode. Pengajar dituntut lebih menguasai bahasa asing dan diharapkan tanpa aksen. Pengajar tidak memposisikan diri sebagai Alleswisser. Sementara pembelajar berusaha menguasai bahasa tujuan dengan cara mendengar dan meniru pengajar. Jadi mendengarkan dan mengikutinya atau mengulanginya adalah cara terbaik untuk menguasai bahasa asing. Seperti halnya dengan Grammatik-Übersetzungsmethode, direkte Methode juga tidak lepas dari berbagai kritikan-kritikan diantaranya: Metode ini dianggap tidak memiliki basis yang kuat dalam sistem pendidikan umum, karena dianggap kurang memotivasi pembelajar; kurangnya pengembangan individu; pengajaran dianggap sangat sempit; tidak dilandasi oleh dasar-dasar ilmiah; terlalu mengesampingkan pengetahuan gramatika.

\section{Audio-linguale Methode}

Audio-linguale Methode dikenal pula dengan istilah Army Method, New Key Method, Pattern Method, Habit-Formation Method, Oral Approach. Dalam bahasa Jerman metode ini diterjemahkan menjadi Hör-Sprech-Methode. Tujuan dari metode ini adalah mempercepat penguasaan kompetensi berbicara, pemahaman bahasa tidak berbasis pada aturan-aturan gramatikalis, melainkan melalui pola kalimat yang kemudian diulang-ulang agar bisa menjadi kebiasaan. Audio-linguale Methode dikembangkan pertama kali di Amerika Serikat antara tahun 1941 dan 1943. Pengembangan metode ini akibat dari permintaan penguasaan berbagai bahasa selain bahasa Inggris terutama setelah perang dunia kedua. Adapun dasar pembelajaran psikologis dari metode ini adalah strukturalismus dan behaviorismus.

Dalam penerapan metode ini, empat keterampilan berbahasa tetap menjadi acuan utama dengan pola urutan: Hören (mendengar) ; Sprechen (berbicara); Lesen (membaca); Schreiben (menulis). Pembelajaran bahasa asing dengan metode ini juga bersifat situativ dengan menggunakan bahan-bahan ajar yang mengangkat situasi keseharian (Alltagssituation). Jenis latihan yang digunakan antara lain: 
- Pembentukan pola-pola kalimat yang variatif (pattern drill).

- Latihan mengganti-ganti bagian-bagian kalimat tertentu. (Satzschalttafeln/Substitutionsübungen).

- Latihan melengkapi bacaan (Lückentexte).

- Menghafal dan meniru model-model dialog tertentu.

\section{Kommunikative Methode}

Kommunikative Methode adalah metode yang dikembangkan untuk penguasaan bahasa asing yang bersifat keseharian, pemahaman fenomena budaya keseharian, pengembangan sikap-sikap keterbukaan, toleransi, kesiapan berkomunikasi dengan budaya tujuan (Jerman). Tema-tema yang diangkat dengan menggunakan metode ini adalah tema-tema yang bisa menjembatani antara budaya sendiri dan budaya asing dengan tetap memperhatikan umur pembelajar (Altersspezifik) dan menggunakan tema-tema yang bersifat universal(universelle Themen). Ciri utama dari metode ini adalah sangat dekat dengan kehidupan keseharian, realistis, praktis dan bisa langsung digunakan.

Kommunikative Methode mulai dikembangkan antara tahun $70 a n$ dan $80 a n$ dengan prinsip penerapan yang bertolak belakang dengan audio-linguale Methode atau pattern-drill Methode. Dalam kommunikative Methode pembelajar diarahkan untuk mampu menguasai dan mengatasi berbagai situasi kebahasaan yang berbeda dan mengembangkan kemampuan berkomunikasi (kommunikative Kompetenz)pembelajar. Jenis latihan yang digunakan dalam metode ini selalu berorientasi pada aspek-aspek sosial (Lernerorientierte Sozialformen) dan biasanya dalam bentuk:

- Kerja kelompok (Gruppenarbeit)

- Membuat kegiatan-kegiatan pembelajaran sendiri (Projektunterricht)

- Belajar dengan bantuan teman Jerman (Tandem)

- Bermain peran (Rollenspiele und Rollentraining)

- Belajar dengan membuat beberapa tempat pembelajaran (Stationenlernen)

Dengan model latihan di atas, maka dalam proses belajar-mengajar dimungkinkan menggunakan berbagai macam media secara integral. Adapun pengajar dalam metode ini berperan sebagai partner dan konsultan, sementara pembelajar menjadi titik pusat dalam proses belajar-mengajar dengan lebih mengoptimalkan format-format belajar berkelompok untuk menciptakan kontakkontak sosial di antara mereka demi pengembangan potensi bahasa masing-masing. Ada beberapa kelebihan yang dimiliki oleh kommunikative Methode ini, diantaranya: Tidak lagi berorientasi kepada bahasa itu sendiri, melainkan berorientasi kepada spesifik pada kommukative Kompetenz. Pencapaian tujuan tidak sebatas pada kemampuan berbicara, melainkan mengarah kepada semua keterampilan berbahasa. Dan yang lebih penting, bahwa dengan metode ini pembelajar dapat meningkatkan motivasi belajarnya secara lebih baik dan menyenangkan. 


\section{Der Interkulturelle Ansatz (Methode)}

Sejak awal tahun 8oan interkulturelle Ansatz berkembang dan merupakan pengembangan dari kommunikative Methode. Tujuan dari penerapan metode interkultural ini yakni mengembangkan kemampuan berkomunikasi dan kemampuan interkultural pembelajar melalui pengembangan keterampilan berbahasa, pengembangan berbagai strategi dalam berkomunikasi antar-budaya, misalnya kemampuan empati untuk mengikis habis berbagai macam prasangka atau praduga, menormalkan pandangan-pandangan yang bersifat ethnosentrisme.

Metode ini dikembangkan dan ditujukan untuk kelompok pembelajar yang berasal dari berbagai macam latar belakang budaya berbeda. Menurut MüllerJacquier, pembelajaran interkultural atau interkulturelles Lernen adalah suatu proses pembelajaran situatif antara berbagai macam pembelajar dari berbagai budaya. Syarat mutlak terjadinya pembelajaran antarbudaya adalah terjadinya proses komunikasi antarbudaya, dimana antara mereka (pembicara dan pendengar dari dua budaya berbeda) senantiasa terjadi pengalaman-pengalaman budaya (asing).

Dalam era komunikasi saat ini, di mana kontak antara manusia dari berbagai latar-belakang budaya yang berbeda sangat dimungkinkan. Kehadiran internet dengan berbagai fasilitas komunikasinya mampu menghubungkan manusia dengan cepat tanpa mengenal ruang dan waktu. Bentuk-bentuk komunikasi di internet misalnya E-Mail, forum-forum diskusi, Newsgroups, Chatgroups sampai pada Tandemlernen. Internet memang menghadirkan kontak antarbudaya, tetapi tidak secara otomatis menghadirkan pemahaman budaya (Kulturverstehen), karena dialog antarbudaya menuntut adanya kesiapan untuk saling memberi dan menerima (Richter 1998:13).

\section{KESIMPULAN}

Berbagai metode yang dipaparkan secara sederhana dalam tulisan ini tidak bermaksud menunjukkan satu metode tertentu yang sesuai untuk semua konsepkonsep pendidikan dan pengajaran dan memberikan garansi keberhasilan. Namun metode-metode ini merupakan pilihan untuk menentukan mana yang terbaik untuk digunakan, guna mencapai tujuan pendidikan yang telah ditetapkan oleh masingmasing lembaga pendidikan. Jadi yang penting saat ini dalam hubungannya dengan metode adalah proses belajar-mengajar hendaknya berorientasi pada pembelajar, pada pengalaman, kebutuhan, realitas dan berorientasi proses dan lebih penting juga bahwa proses belajar-mengajar itu berlangsung secara kooperatif, interaktif, kesesuaian antara materi dan tugas, ketuntasan, dan bersifat autonom-individuell.

\section{DAFTAR PUSTAKA}

Apelt, W. (1972). Zur Problematik: Sprachwissenschaft und Sprachunterricht.

Deutsch als Fremdsprache, 193.

Hüllen, W. (2005). Kleine Geschichte des Fremdsprachenlernens. Berlin: Erich Schmidt.

Neuner, G. (1995). Methodik und Methode: Überblick. Tübingen. 
52 Eralingua: Jurnal Pendidikan Bahasa Asing dan Sastra Vol.3, No.1, Maret 2019

Neuner, H. (1993). Methoden des fremdsprachlichen Deutschunterricht. Eine Einführung. München: Langenscheidt.

Roche, J. (2008). Fremdsprachenerwerb Fremdsprachendidaktik. Tübingen: Francke. Roche, J. (2001). Interkulturelle Sprachdidaktik. Eine Einführung. Tübingen: Gunter Narr.

Rösler, D. (1994). Deutsch als Fremdsprache. Stuttgart: Metzler. 